\title{
A NEW SOURCE OF THE SYNOPSIS OF JOSEPH RHAKENDYTĖS
}

\author{
Erika GIELEN
}

Joseph Rhakendytès, also called the Philosopher (ca. 1260-ca. 1330), was one of the central figures of the cultural scene of 14th-century Constantinople, counting, among others, Theodorus Metochites and Nicephorus Gregoras among his friends ${ }^{1}$. To this day, his major work $^{2}$, his so-called Synopsis Variarum Disciplinarum, remains for the most part unpublished. Besides the twofold introduction, edited by $\mathrm{Treu}^{3}$ in 1899 , only of the $\Sigma v$ vours $\tau \hat{\eta} \varsigma$ $\dot{\rho} \eta \tau \rho \rho \imath \kappa \hat{\zeta}$, which, based on the manuscript tradition, seems to have been the most popular part of Joseph's Synopsis, a modern, (to some extent) critical edition is available to us ${ }^{4}$, which, however, also itself highly needs revision, given the very limited number of manuscripts used by the editor.

This lack of an easily accessible, sound corpus of texts complicates the search for the sources Joseph has consulted to compose his Synopsis - also, not in the least, because Joseph never mentions his sources by name, writing, instead, as if it were his own words 5 .

Yet, especially at the end of the 19th and in the beginning of the 20th century, several scholars made an attempt to uncover the authors behind Joseph's composition.

1. See especially M. Treu, Der Philosoph Joseph, BZ 8, 1899, p. 1-64.

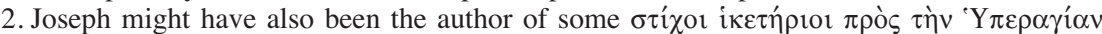

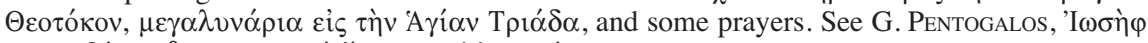



3. M. TREU, art. cit., p. 34-42.

4. C. WAlz, Rhetores Graeci ex codicibus Florentinis, Mediolanensibus, Monacensibus, Neapolitanis, Parisiensibus, Romanis, Venetis, Taurinensibus et Vindobonensibus, III, Osnabrück 1832-1836 (= 1968), p. 478-569.

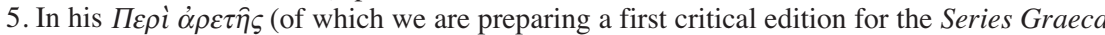

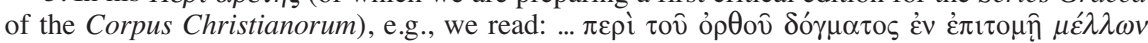

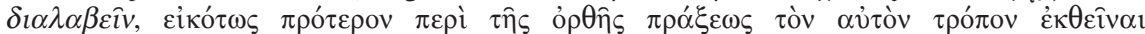
$\pi \rho \eta_{\varphi} \rho \eta \mu \alpha z$. On the other hand, unwilling to condemn Joseph (who lived in 14th-century Byzantium, where ideas on originality different from ours prevailed) as an unrelenting plagiarizer, one should also keep in mind that Joseph, in his introduction, actually had announced that he had "gathered one thing from here, another from there, a third from a third place and again another thing from yet another source", using older, as well as more recent sources. See M. TREU, art. cit., p. $37^{25}-38^{3}$.

Revue des Études Byzantines 69, 2011, p. 265-270. 
In 1894, Vitelli gave a detailed description of the content of the 14th-century manuscript Florentinus Riccardianus gr. 31 (K.II.4) ${ }^{6}$. This paper codex, which consists of 383 folios, contains the complete Synopsis of Joseph. As for the sources, Vitelli was able to identify the original authors of the following

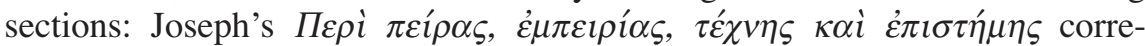
sponds to parts of the Epitome logica of Nicephorus Blemmydes; parts of

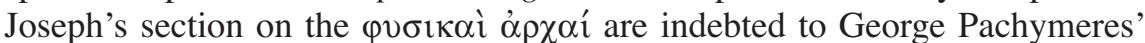


$\dot{\alpha} \rho \varepsilon \tau \hat{\eta} \varsigma$ was copied from Maximus the Confessor; and for the last section of his Synopsis, Joseph got his information from Blemmydes and Cyril of Alexandria.

Eight years after Vitelli, Terzaghi ${ }^{7}$ tried to complete Vitelli's overview.

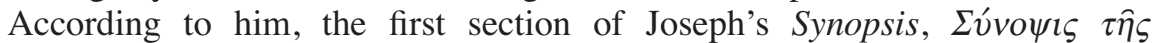
$\dot{\rho} \eta \tau о \rho \imath \kappa \eta \zeta$, was taken from an anonymous author ${ }^{8}$, who strongly depended on the work of the late-antique rhetor Hermogenes. He also pointed to some resemblance of Joseph's text to the De anima of Alexander Aphrodisiensis, and to some more overlaps between Joseph and Pachymeres. Moreover, he

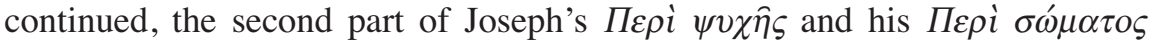
correspond to Blemmydes' treatises with the same titles ${ }^{9}$. In 1974, Criscuolo ${ }^{10}$ refined Terzaghi's assertion, stating that, for some passages, not Alexander Aphrodisiensis was the direct source of Joseph's, but the 12th-century commentator of Aristotle Michael of Ephesus, reproducing some parts of Alexander's work.

Now, as we are finalizing our critical edition of Joseph's $\Pi \varepsilon \rho i \dot{\alpha} \rho \varepsilon \tau \hat{\eta} \varsigma$, the second last part of the Synopsis, we are able to indicate the correct source of yet another section of Joseph's magnum opus.

Treu ${ }^{11}$ asserted that Joseph "die Tugend nach dem Anonymus Christianus behandelt", thus following Vitelli, who had noticed that the text of Joseph's $\Pi \varepsilon \rho i \dot{\alpha} \rho \varepsilon \tau \eta \hat{\zeta}$ corresponds to the anonymi Christiani philosophi liber de vir-

6. G. Vitelli, Indice de' codici greci Riccardiani, Magliabechiani e Marucelliani, Studi Italiani di filologia classica 2, 1894, p. 471-570 (here p. 490-493).

7. N. Terzaghi, Sulla composizione dell'Enciclopedia del filosofo Giuseppe, Studi Italiani di filologia classica 10, 1902, p. 121-132.

8. For this, Terzaghi based himself on Treu, who stated that "es liegt also auch auf der Hand, dass wir auch die Synopsis der Rhetoric... nicht für die eigene Arbeit Josephs halten dürfen. Auch dieser Teil muss in wesentlicher Anlehnung an Hermogenes einem anderen Byzantinischer gehören" (see M. TREU, art. cit., p. 46).

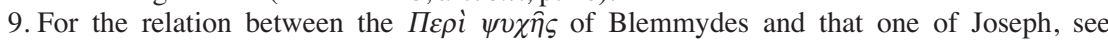

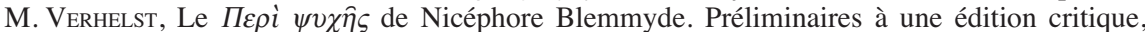
BF 4, 1972, p. 214-219; EADEM, Le "Traité de l'âme" de Nicéphore Blemmyde. Histoire du texte, édition critique, traduction et analyse du contenu doctrinal. Thèse présentée pour l'obtention du grade de Docteur en Philosophie et Lettres, I, Université Catholique de Louvain. Faculté de Philosophie et Lettres 1976 (unpublished), p. 279-283.

10. R. Criscuolo, Note sull'Enciclopedia del filosofo Giuseppe, Byz. 44, 1974, p. 255-281.

11. M. TREU, art. cit., p. 46. 
tute, edited in Augsburg by Johannes Wegelinus in $1603^{12}$. Yet, this 17 th-century text is, in fact, not an edition of Joseph's source text, but nothing else but an edition of Joseph's own text, based on the 16th-century manuscript Augustanus, Staats- und Stadtbibliothek, $2^{\circ}$ Cod. $240^{13}$. Where, then, did Joseph take his text from?


taken from Maximus the Confessor's Ad sanctissimum presbyterum Marinum $(C P G 7697.1)^{14}$. Yet, as we discovered after a detailed comparison with various ethical treatises of the Byzantine period, the text in which the Maximuspassages are embedded, was not itself from the pen of the church father also, but reproduces more or less in full the (nowadays rather unknown) treatise $\Pi \varepsilon \rho i \dot{\alpha} \rho \varepsilon \tau \hat{\eta} \varsigma \kappa \alpha i \dot{\alpha} \sigma \kappa \dot{\gamma} \sigma \varepsilon \omega \varsigma$ of Nicephorus Blemmydes, for whom Joseph seems to have had a special predilection, considering the rather large number of Blemmydian works on which Joseph drew for the composition of his own Synopsis. On his ethical treatise, which he probably composed around 1263, Blemmydes wrote the following himself: "I composed a book On faith and another On virtue and asceticism: I particularly made plain all that a person who chooses to lead a really pious life should not ignore and should not leave undone" 15 .


(the only edition being the editio princeps by Voulismas in $1784{ }^{16}$ ), we are also preparing a critical edition of this text ${ }^{17}$, so there is a solid basis for a well-considered comparison of Joseph's text and its source.

This, perhaps, will also enable us to determine - previously undone which manuscript Joseph may have had at hand while compiling his Synopsis,

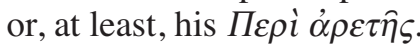

Of course, we may not lose sight of the (quite reasonable) possibility that this 'source manuscript' of Joseph's got lost. Moreover, up to now, we still

12. G. Vitelli, art. cit., p. 492; Anonymi Christiani philosophi liber de virtute. E ms. codice graeco, iamprimum editus, latinitate donatus, et hypomnematis illustratus a Iohanne Wegelino Augustano, Augustae Vindelicorum 1603.

13. H. SPILling, Handschriftenkataloge der Staats- und Stadtbibliothek Augsburg,

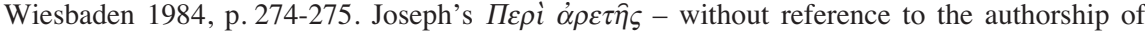
Joseph - can be found on f. 35-57.

14. This letter can be found in $P G 91,9-37$. The passages used by Joseph are $P G 91,12^{32}$ $24^{26}$. A new edition of this text is currently being prepared by Dr. B. Markesinis for the Series Graeca of the Corpus Christianorum.

15. Nicephorus Blemmydes, Autobiographia, II, 7511-14. See J. A. Munitiz, Nikephoros Blemmydes. A Partial Account. Introduction, Translation and Notes (Spicilegium Sacrum Lovaniense. Études et Documents 48), Leuven 1988, p. 27 and 133.



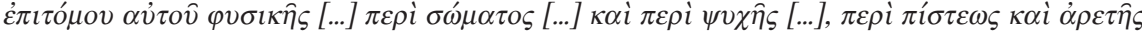

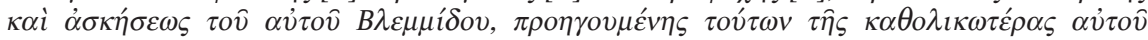
$\dot{\varepsilon} \pi \iota \tau \tau \sigma \lambda \hat{\eta} \varsigma$, ed. D. Voulismas, III, Lipsiae 1784, p. 121-140.

17. This text will appear in the same volume of the Series Graeca of the Corpus

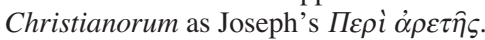


were not able to get hold of (a reproduction of) all the manuscript witnesses

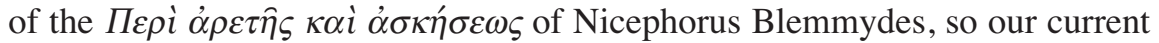
suggestions are just preliminary results. Nonetheless, of the manuscripts that have already been subject of our research, there were some especially worth considering in this respect, and a close comparison of these with Joseph's text enabled us to at least already decrease the group of probable candidates by two.

First of all, indeed, our attention was immediately drawn by manuscript Monacensis gr. 225, as it contains both Blemmydes' ethical treatise (f. 359373) and Maximus the Confessor's Letter to Marinus (f. $2^{v}-6^{v}$ ). Unfortunately, unnoticed by Hardt ${ }^{18}$, this codex turned out to consist, in fact, of two separate parts (the first devoted to Maximus the Confessor, the second to Nicephorus Blemmydes) of different time and origin and which were joined together only in the 16th century, when acquired for the Fugger library in Augsburg ${ }^{19}$.

Secondly, we turned our attention to manuscript Romanus Vallicellianus gr. 30 (C4) ${ }^{20}$, since it had been suggested as possible source manuscript of Joseph by Kontouma-Conticello ${ }^{21}$, containing quite a lot of texts that possibly form the basis of parts of Joseph's Synopsis - among them, also Blemmydes' $\Pi \varepsilon \rho i \dot{\alpha} \rho \varepsilon \tau \eta \hat{\varsigma} \varsigma \alpha \dot{i} \alpha \dot{\alpha} \kappa \dot{\eta} \sigma \varepsilon \omega \varsigma$. Yet, based on our collation, also this manuscript is definitely to be excluded as Joseph's model, since none of the variant readings with which Joseph's text distinguishes itself from Blemmydes' text ${ }^{22}$, is present in this 14th-century witness of Blemmydes' ethical treatise.

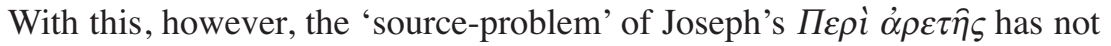
been solved completely. The end of Joseph's treatise does not, indeed, coin-

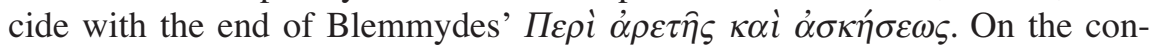
trary, after having copied the last paragraph of Blemmydes' text, Joseph adds twelve more paragraphs (in the edition of Wegelinus) ${ }^{23}$, discussing first how

18. I. HARDT, Catalogus codicum manuscriptorum Bibliothecae Regiae Bavaricae, II, Seidel 1806, p. 462-471.

19. See J. H. Declerck, Maximi Confessoris quaestiones et dubia (Corpus Christianorum, Series Graeca 10), Turnhout-Leuven 1982, p. LXxxviII; J. A. Munitiz, Nicephori Blemmydae autobiographia sive curriculum vitae, necnon epistula universalior (Corpus Christianorum, Series Graeca 13), Turnhout-Leuven 1984, p. XVIII-XXI; B. MARKESINIS, Le Monacensis gr. 225, ff. 1 $^{\mathrm{r}}-40^{\mathrm{v}}$, et Georges de Chypre, alias Grégoire II de Constantinople, Bollettino della Badia Greca di Grottaferrata 54 (n.s.), 2000, p. 259-273 (here p. 259-262); B. Janssens, Maximi Confessoris ambigua ad Thomam, una cum epistula secunda ad eundem (Corpus Christianorum, Series Graeca 48), Turnhout-Leuven 2002, p. LXII-LXIII.

20. E. MartinI, Catalogo di manoscritti greci esistenti nelle biblioteche italiane, II, Milano 1902 , p. $48-54$

21. V. Conticello, Pseudo-Cyril's De SS. Trinitate. A Compilation of Joseph the Philosopher, OCP 61, 1995, p. 117-129 (here p. 129). According to her, the De SS. Trinitate is a

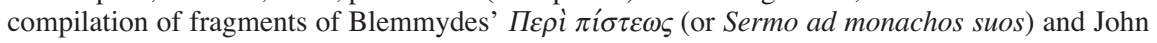
Damascene's Expositio Fidei by Joseph. All those passages seem to be present in manuscript Romanus Vallicellianus gr. 30.

22. These will be discussed more in detail in the forthcoming edition of the ethical treatises of Joseph and Blemmydes.

23. Anonymi Christiani philosophi liber de virtute, ed. J. WegeLINus, paragraph 27-39. 
"the sage of olden times, having advanced many and diverse theses on this topic", dealt with philosophy and ethics ${ }^{24}$, then describing in short, once more, the four cardinal virtues with their respective vices, and the most important 'minor' virtues, also accompanied by their vices.

Intriguingly, in one manuscript containing almost the complete Synopsis of Joseph, Florentinus Mediceus-Laurentianus gr. plut. 58, 20 (14th century) ${ }^{25}$, Joseph's $\Pi \varepsilon \rho i \alpha \rho \varepsilon \tau \eta \bar{\varsigma}$ stops with the last words of Blemmydes' treatise on virtue (.. $\tau \varepsilon \theta \varepsilon \hat{\omega} \sigma \theta \alpha 1, \mu \alpha \kappa \alpha \rho i \omega \tau \alpha \tau o \varsigma$ on f. $\left.372^{v}\right)$, thus omitting the overview of the ancient philosophers and that one of the virtues ${ }^{26}$. Moreover, in the margins of manuscript Florentinus Riccardianus gr. 31, already mentioned, at the end of Blemmydes' text (f. 353), we read ع้v $\alpha \rho \xi_{1 \varsigma}$, thus suggesting another, new passage (of a different author?) starts.

At this moment, we have not yet identified the original author of this passage. Maybe, we should even not rule out the possibility that Joseph has actually written this part himself. He seems to have set great store by a high degree of clarity of the text for the reader ${ }^{27}$, and such a summarizing chapter seems to fit quite well with this intention. Yet, given the highly reproducing and - from a modern point of view - 'unoriginal' character of the whole Synopsis, and more specifically now, of the first part of Joseph's $\Pi \varepsilon \rho i \dot{\alpha} \rho \varepsilon \tau \hat{\eta} \varsigma$, this option seems less likely. Moreover, very recently, we discovered two manuscripts, Vindobonensis phil. gr. 192 (15th century) ${ }^{28}$ and Venetus Marcianus gr. IV, 43 (16th century) ${ }^{29}$, which seem to contain both a (anonymous) text 'de virtutibus' that apparently starts with the very same statement on "the elder sages", that they "have advanced many diverse theses on

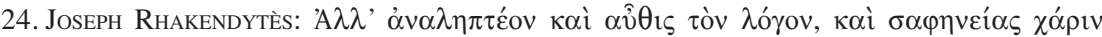

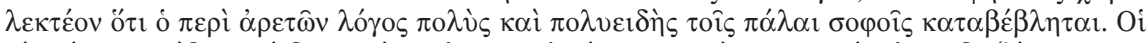

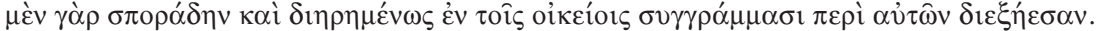

25. A M. Bandini, Catalogus codicum manuscriptorum Bibliothecae Mediceae Laurentianae varia continens opera graecorum patrum, II, Firenze 1764-1770 (= 1961), col. 459-462. Sections of Joseph's Synopsis that are not present in this codex are the prose- and verse-introduction, a chapter of the treatise $\Pi \varepsilon \rho i \alpha i \sigma \theta \eta \dot{\sigma} \sigma \omega \varsigma \kappa \alpha i \alpha i \sigma \theta \eta \tau \hat{\omega} v$, both letters of John Zacharias

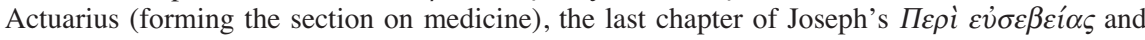
the following fragments attributed to Cyril of Alexandria.

26. Instead, we find the pseudo-Aristotelian treatise De virtutibus et vitiis (f. $\left.372^{\mathrm{v}}-374\right)$, in

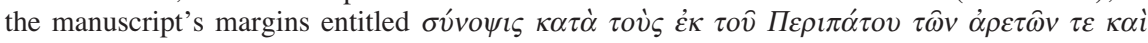
$\tau \hat{\omega} v \kappa \alpha \kappa \imath \hat{\omega} v$ by a later reader.

27. In his introduction, e.g., Joseph proclaims that "on the spot [his reader] will understand that which is useful and he will not shrink from things that come quickly one after another", and that "he has collected all those things and has made them plain and clear" (M. TREU, art. cit., p. $38^{13-20}$ ). Another (small) example is given by R. CRISCUOLO, art. cit., p. 265, while discussing

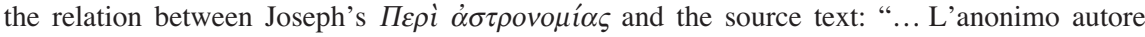
elenca i nomi egizi dei mesi; Giuseppe, per maggior chiarezza, sovrappone a ciascuno il corrispondente nome latino, grecizzato, s'intende. Mutamenti di siffatto genere, frequenti in ogni parte dell'Enciclopedia...".

28. H. Hunger, Katalog der griechischen Handschriften der Österreichischen Nationalbibliothek, I (Museion. Veröffentlichungen der Österreichischen Nationalbibliothek. Neue Folge 4.1.1), Wien 1961, p. 301-303.

29. E. Mioni, Bibliothecae Divi Marci Venetiarum codices Graeci manuscripti, I/2, Roma 1972, p. 231-232. 


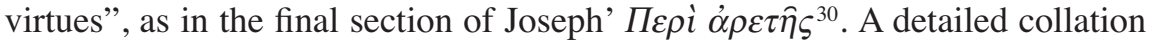
and comparison of both texts with Joseph's text will (hopefully) prove whether or not we are dealing here with other witnesses of the original source

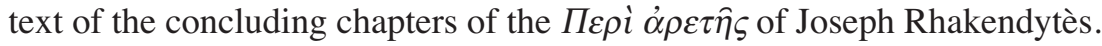

Erika GieLEN

Katholieke Universiteit Leuven

30. Cf. supra, note 24 .

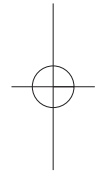

